\title{
Effects of probiotic and prebiotic (mannanoligosaccharide) supplementation on performance, egg quality and hatchability in quail breeders
}

\author{
Berrin KOCAOĞLU GÜÇLÜ
}

Department of Animal Nutrition and Nutritional Diseases, Faculty of Veterinary Medicine, University of Erciyes, Kayseri, Turkey

\begin{abstract}
Summary: This study was performed to investigate the effects of probiotic and prebiotic (mannanoligosaccharide) supplementation on performance, egg quality and hatchability in quail breeders. Four hundred and eighty, 18 wk old Japanese quail (Coturnix coturnix japonica) were evenly distributed to 5 groups with four replicates containing 24 (18 female, 6 male) quail in each. Quail were fed either basal diet (control group) or 0.5 and $1 \mathrm{~kg} /$ ton probiotic and prebiotic supplemented basal diets (treatment groups) for 12 weeks. The live weight of animals, egg production, feed consumption and egg weight were recorded, and feed efficiency was calculated. Egg quality, fertility and hatchability were also determined. Supplementation of 0.5 and $1 \mathrm{~kg} / \mathrm{ton}$ prebiotic to diet increased the live weight $(\mathrm{p} \leq 0.001)$ and egg production $(\mathrm{p} \leq 0.01)$, respectively while $0.5 \mathrm{~kg} /$ ton probiotic increased egg production $(\mathrm{p} \leq 0.01)$. Egg shell thickness was improved by both supplements $(\mathrm{p} \leq 0.05)$. Neither probiotic nor prebiotic supplementation to the diets had significant effects on feed consumption, feed efficiency and egg weight, egg specific gravity, albumen index, yolk index, and Haugh unit. Probiotic and prebiotic supplementation slightly but not significantly increased percentage of fertile egg and hatchability. In conclusion, supplementation of probiotic and prebiotic (MOS) to the diet of quail breeders positively affected egg production and egg shell thickness.
\end{abstract}

Key words: Hatchability, performance, prebiotic, probiotic, quail breeders

\section{Damızlık bıldırcınlarda rasyona probiotik ve prebiotik (mannanoligosaccharide) katılmasının performans, yumurta kalitesi ve kuluçka performansı üzerine etkileri.}

Özet: Bu çalışma, rasyona probiyotik ve prebiyotik (mannanoligosaccharide) katılmasının damızlık bıldırcınlarda performans, yumurta kalitesi ve kuluçka performansı üzerine etkilerini belirlemek amacıyla yapılmıştır. Çalışmada, 480 adet 18 haftalık Japon bıldırcını (Coturnix Coturnix japonica), her grupta 24 adet (18 dişi, 6 erkek) olacak şekilde 4 tekrarlı 5 gruba ayrılmıştır. Bıldırcınlar bazal rasyon (kontrol grubu) veya 0,5 ve $1 \mathrm{~kg} /$ ton probiyotik ya da prebiyotik ilave edilen (deneme grupları) bazal rasyonlarla 12 hafta süresince beslenmiştir. Çalışmada, bıldırcınların canlı ağırlığı, yumurta verimi, yem tüketimi, yumurta ağırlıkları ve yemden yararlanma oranları ile yumurta kalitesi, fertilite ve kuluçka performansı belirlenmiştir. Rasyona $0,5 \mathrm{~kg} /$ ton prebiyotik ilavesi canlı ağırlı̆g $1(\mathrm{p} \leq 0.001)$ ve $0,5 \mathrm{~kg} /$ ton probiyotik ile $1 \mathrm{~kg} /$ ton prebiyotik ilavesi yumurta verimini $(\mathrm{p} \leq 0.01)$ arttırmıştır. Yumurta kabuk kalınlığ hem probiyotik hem de prebiyoik katılan gruplarda artmıştır $(\mathrm{p} \leq 0.05)$. Gerek probiyotik gerekse prebiyotik ilavesinin yem tüketimi, yemden yararlanma oranı, yumurta ağırlığı, yumurta özgül ağırlı̆̆ı, ak indeksi, sarı indeksi ve Haugh birimine önemli bir etkisi olmamıştır. Döllü yumurta oranı ve kuluçka performansı istatistiki önemde olmamakla birlikte probiyotik ve prebiyotik ilave edilen gruplarda iyileşme göstermiştir. Damızlık bıldırcın yemlerine probiyotik ya da prebiyotik katılmasının yumurta verimi ve yumurta kabuk kalitesini olumlu yönde etkilediği sonucuna varılmıştır.

Anahtar sözcükler: Damızlık bıldırcın, kuluçka performansı, prebiyotik, probiyotik, verim performansı.

\section{Introduction}

In recent years, use of probiotics, prebiotics and symbiotics that enrich certain bacterial population in the digestive system are considered as alternatives to antibiotic growth promotants in poultry nutrition $(24,32)$.

Probiotics, microbial cell preparations, that are mono or mixed cultures of live, protective microorganisms beneficially affect the host animal by competing with other microorganisms for adhesive site. They stimulate appetite, improve host's intestinal microbial balance and intestinal environment for processes of the digestion and absorption of nutrients. They also inhibit certain pathogens that produce toxic compounds $(19,24)$.

Prebiotics, non-digestible feed ingredients, have selective effects on the intestinal microflora. They are consisting of nondigestible oligosaccharides which include fructooligosaccharide, galactooligosaccharide, transgalactooligosaccharide and mannanoligosaccharide (MOS) $(10,11,24,32)$. The MOS, derived from the cell 
wall of Saccharomyces cerevisiae, is neither hydrolysed by endogenous digestive enzymes nor absorbed by host, and it is considered as an prebiotic agent. It has been claimed that the benefits of MOS based on its specific properties such as modification of the intestinal flora, reduction in turnover rate of the intestinal mucosa and modulation of the immune system. These properties have the potential to enhance growth rate, feed efficiency and liveability in commercial broiler and turkeys, and egg production in layers (31).

In recent years, breeding of quail has taken an important place in alternative poultry production. Many factors such as hatchability and fertility rate, male/female ratio, genetics, age, egg quality, nutritional status and live weight of breeders affect quail's performance (30). To the author's knowledge, there have been limited studies investigating the effects of probiotics and prebiotics on performance of broiler breeders (32) but there is no study in quail breeders. Moreover, controversial results have been reported regarding the use of biological additives to poultry diets $(7,13,23,26)$. Therefore, this study was performed to investigate the effects of probiotic and prebiotic supplementation on feed consumption, feed efficiency, egg production, exterior and interior egg quality and hatchability of quail breeders.

\section{Materials and Methods}

Animals, diets and management: Four hundred and eighty 18 wk-old Japanese quail (Coturnix coturnix japonica) were weighed to equal live weight in all groups at the beginning of the study. They evenly distributed to 5 groups with four replicates containing 24 (18 female, 6 male) quail in each following one week of adaptation period. Quails were fed either basal diet (Table 1) containing $20 \%$ crude protein and $2800 \mathrm{kcal} / \mathrm{kg}$ metabolizable energy (control group) or 0.5 and $1 \mathrm{~kg} /$ ton probiotic or prebiotic supplemented basal diets (treatment groups) for 12 weeks. A commercially available probiotic preparation (Novartis International AG, Türkiye) which were used in the study contained strains of bacteria and yeasts (Lactobacillus plantarum, $1.89 \times 10^{10} \mathrm{cfu} / \mathrm{kg}$, Lactobacillus delbrueckii subsp. bulgaricus $3.09 \times 10^{10} \mathrm{cfu} / \mathrm{kg}$, Lactobacillus acidophilus $3.09 \times 10^{10} \mathrm{cfu} / \mathrm{kg}$, Lactobacillus rhamnosus $3.09 \times 10^{10}$ cfu $/ \mathrm{kg}$, Bifidobacterium bifidum $3.00 \times 10^{10} \mathrm{cfu} / \mathrm{kg}$, Streptococcus salivarius subsp. thermophilus $6.15 \times 10^{10}$ cfu $/ \mathrm{kg}$, Enterococcus faecium $8.85 \times 10^{10} \mathrm{cfu} / \mathrm{kg}$, Aspergillus oryza $7.98 \times 10^{9} \mathrm{cfu} / \mathrm{kg}$, Candida pintolopesii $7.98 \times 10^{9} \mathrm{cfu} / \mathrm{kg}$ ). Mannanoligosaccharide, a commercial prebiotic preparation that is derived from Saccharomyces cerevisiae (S.I.Lesaffre, Cedex, France), was used in this study. Quail were allowed ad libitum access to feed and water, and they were housed in stainless-steel wire cages on a 17-h lighting schedule. Chemical composition of the diet was analyzed by the methods of AOAC (2). The metabolizable energy was calculated from the sum of the reference values of all ingredients that indicated by Ergün ve ark (9).

Table 1. Ingredients and chemical composition of basal diet Tablo 1. Bazal rasyonun içeriği ve kimyasal bileşimi

\begin{tabular}{|c|c|}
\hline Ingredients & $\%$ \\
\hline Corn & 38.00 \\
\hline Soybean meal & 25.00 \\
\hline Sunflower meal & 10.00 \\
\hline Barley & 12.70 \\
\hline Meat-bone meal & 2.00 \\
\hline Vegetable oil & 4.00 \\
\hline Limestone & 7.30 \\
\hline DCP & 0.40 \\
\hline Sodium chloride & 0.30 \\
\hline Vitamin premix $^{\mathrm{a}}$ & 0.15 \\
\hline Mineral premix ${ }^{\mathrm{b}}$ & 0.15 \\
\hline \multicolumn{2}{|l|}{ Chemical composition } \\
\hline Dry matter,\% & 90.90 \\
\hline Crude protein, $\%$ & 20.33 \\
\hline Crude ash, $\%$ & 12.14 \\
\hline Metabolizable energy ${ }^{\mathrm{c}}, \mathrm{kcal} / \mathrm{kg}$ & 2800 \\
\hline \multicolumn{2}{|c|}{$\begin{array}{l}\text { a Each kg of vitamin premix contains } 6000000 \mathrm{IU} \text { vit } \mathrm{A}, 600 \\
000 \mathrm{IU} \text { vit } \mathrm{D}_{3} 20000 \mathrm{IU} \text { vit } \mathrm{E}, 2 \mathrm{~g} \text { vit } \mathrm{K}, 1.2 \mathrm{~g} \text { vit } \mathrm{B}_{1}, 2.4 \mathrm{~g} \text { vit } \\
\mathrm{B}_{2}, 2 \mathrm{~g} \text { vit } \mathrm{B}_{6}, 12 \mathrm{mg} \text { vit } \mathrm{B}_{12}, 10 \mathrm{~g} \text { niasin, } 300 \mathrm{mg} \text { folic acid, } 4 \\
\mathrm{~g} \text { calcium pantothenate } 50 \mathrm{mg} \text { D-Biotin. } \\
\mathrm{b} \text { Each } \mathrm{kg} \text { of mineral premix contains } 80 \mathrm{~g} \mathrm{Mn}, 30 \mathrm{~g} \mathrm{Fe}, 60 \mathrm{~g} \\
\mathrm{Zn}, 5 \mathrm{~g} \mathrm{Cu}, 0.5 \mathrm{~g} \mathrm{Co}, 2 \mathrm{~g} \mathrm{I}, 235.68 \mathrm{~g} \mathrm{Ca} \text {. } \\
{ }^{\mathrm{c}} \text { The metabolizable energy was calculated from the sum of the } \\
\text { reference values of all ingredients that indicated by Ergün ve } \\
\text { ark (9) }\end{array}$} \\
\hline
\end{tabular}

Performance and egg quality measurements: The live weight of animals was recorded at the beginning and at the end of the study. Egg production was recorded daily, the feed consumption and egg weight were recorded at two weekly intervals. Feed efficiency was calculated by determining of the amount of feed consumed for one $\mathrm{kg}$ of egg.

Twenty eggs from each group were collected to determine the interior and exterior egg quality at monthly intervals. Specific gravity of a whole egg $\left(\mathrm{g} / \mathrm{cm}^{3}\right)$ was measured by Archimedes's method at the same day of egg collection $(16,34)$. The other egg quality parameters were measured 24 hours after collection. Egg shell thickness was determined by mean value of three measurements taken from three different sides of the shell. Albumen height, length and width were measured and then albumen index was calculated. Yolk height and diameter were measured to calculate the yolk index. Haugh unit was calculated with following formula where 
the $\mathrm{H}_{\mathrm{A}}$ is albumen height and $\mathrm{W}_{\mathrm{E}}$ is egg weight [Haugh unit $\left.=100 \log \left(\mathrm{H}_{\mathrm{A}}+7.57-1.7 \mathrm{~W}_{\mathrm{E}}{ }^{0.37}\right)\right](35)$.

Determination of hatchability: One hundred and fifty eggs from each group were collected during the last week of the study. The eggs that have the suitable characteristics for the brooding were placed at a brooder on the group basis. The number of the hatched chicks were recorded for three days after $17^{\text {th }}$ days of brooding. Then the remaining non-hatched eggs were cracked, and the fertile, unfertile eggs and embryonic deaths were recorded. The hatchability characteristics were calculated by the following formulas (1).

Fertility $=$ number of fertile eggs/number of total eggs set the brooder $\mathrm{x} 100$

Hatchability (fertile egg set) $=$ number of hatched chicks/number of fertile eggs set the brooderx 100

Hatchability (total egg set) =number of hatched chicks/number of total eggs set the brooderx 100

Statistical analyses: Statistical analyses of data were performed by SPSS 10.0 version for Windows. One-way analysis of variance (ANOVA) was used for the differences between groups. When the $\mathrm{F}$ values were significant, Duncan's Multiple Range Test was performed. All data were expressed as means \pm SEMs (22).

\section{Results}

The final live weight of the quails fed $0.5 \mathrm{~kg} / \mathrm{ton}$ MOS supplemented diet was significantly higher than control and other treatment groups. Supplementation of $0.5 \mathrm{~kg} /$ ton probiotic and $1 \mathrm{~kg} /$ ton $\mathrm{MOS}$ to the diets increased egg production. No significant differences were found between groups with regard to feed consumption, feed efficiency and egg weight (Table 2).

Egg shell thickness was significantly higher in all treatment groups except $1 \mathrm{~kg} /$ ton MOS supplemented group than control. Neither probiotic nor MOS supplementation to the diets significantly affected egg specific gravity, albumen index, yolk index and Haugh unit (Table 2). Although statistically not significant, probiotic and MOS supplementation slightly increased percentage of fertile egg and hatchability (Table 3 ).

Table 2. Effects of dietary probiotic and prebiotic supplementation on performance and egg quality Tablo 2.Rasyona probiyotik ve prebiyotik katılmasının performans ve yumurta kalitesine etkisi

\begin{tabular}{|c|c|c|c|c|c|c|}
\hline & \multirow[t]{2}{*}{ Control } & \multicolumn{2}{|c|}{ Probiotic, kg /ton } & \multicolumn{2}{|c|}{ Prebiotic, kg/ton } & \multirow[t]{2}{*}{$\mathrm{p}$} \\
\hline & & 0.5 & 1 & 0.5 & 1 & \\
\hline Initial body weight, $g$ & $228.00 \pm 2.88$ & $225.04 \pm 2.95$ & $228.85 \pm 2.84$ & $228.09 \pm .2 .39$ & $228.12 \pm 2.31$ & - \\
\hline Final body weight, $g$ & $227.71 \pm 2.96^{\mathrm{b}}$ & $230.56 \pm 2.62^{b}$ & $236.00 \pm 3.23^{\mathrm{b}}$ & $246.23 \pm 3.56^{\mathrm{a}}$ & $230.55 \pm 4.28^{\mathrm{b}}$ & $* * *$ \\
\hline Egg production, $\%$ & $79.76 \pm 1.55^{\mathrm{b}}$ & $84.63 \pm 0.51^{\mathrm{a}}$ & $82.79 \pm 1.16^{\mathrm{ab}}$ & $80.07 \pm 0.90^{\mathrm{b}}$ & $86.18 \pm 1.25^{\mathrm{a}}$ & $* *$ \\
\hline Feed consumption, $\mathrm{g}$ & $36.88 \pm 1.38$ & $36.99 \pm 0.56$ & $37.93 \pm 1.21$ & $36.10 \pm 0.42$ & $36.23 \pm 0.62$ & - \\
\hline Egg weight, $g$ & $12.04 \pm 0.17$ & $11.70 \pm 0.03$ & $11.64 \pm 0.23$ & $11.83 \pm 0.18$ & $12.07 \pm 0.08$ & - \\
\hline Feed efficiency, $\mathrm{kg}$ feed/kg egg & $3.84 \pm 0.12$ & $3.73 \pm 0.13$ & $3.93 \pm 0.06$ & $3.81 \pm 0.09$ & $3.61 \pm 0.07$ & - \\
\hline Specific gravity, $\mathrm{g} / \mathrm{cm}^{3}$ & $1.0583 \pm 0.001$ & $1.0609 \pm 0.001$ & $1.0601 \pm 0.002$ & $1.0633 \pm 0.002$ & $1.0589 \pm 0.001$ & - \\
\hline Egg shell thickness, $\mathrm{mmx} 10^{-2}$ & $19.48 \pm 0.19^{\mathrm{b}}$ & $20.16 \pm 0.16^{\mathrm{a}}$ & $20.36 \pm 0.26^{\mathrm{a}}$ & $20.21 \pm 0.23^{\mathrm{a}}$ & $19.79 \pm 0.24^{\mathrm{ab}}$ & $*$ \\
\hline Albumen index & $8.68 \pm 0.22$ & $9.20 \pm 0.26$ & $9.11 \pm 0.37$ & $9.44 \pm 0.54$ & $9.12 \pm 0.33$ & - \\
\hline Yolk index & $41.02 \pm 0.68$ & $42.03 \pm 0.69$ & $43.36 \pm 0.70$ & $41.09 \pm 0.73$ & $41.32 \pm 0.63$ & - \\
\hline Haugh unit & $81.64 \pm 0.59$ & $82.68 \pm 0.61$ & $82.30 \pm 0.94$ & $83.36 \pm 1.21$ & $82.11 \pm 0.72$ & - \\
\hline Yolk colour & $6.75 \pm 0.11^{\mathrm{bc}}$ & $7.10 \pm 0.10^{\mathrm{a}}$ & $6.58 \pm 0.09^{c}$ & $7.03 \pm 0.15^{\mathrm{ab}}$ & $7.25 \pm 0.09^{\mathrm{a}}$ & $* *$ \\
\hline
\end{tabular}

a-b: The mean values within each row with different superscripts differ significantly.

$*: \mathrm{p}<0.05, * *: \mathrm{p}<0.01, * * *: \mathrm{p}<0.001$

-: not significant

Table 3. Effects of dietary probiotic and prebiotic supplementation on hatchability and fertile egg

Tablo 3. Rasyona probiyotik ve prebiyotik katılmasının kuluçka performansı ve döllü yumurta oranına etkisi*

\begin{tabular}{lccccc}
\hline & Control & \multicolumn{2}{c}{ Probiotic, $\mathrm{kg} /$ ton } & \multicolumn{2}{c}{ Prebiotic, $\mathrm{kg} /$ ton } \\
& & 0.5 & 1 & 0.5 & 1 \\
\cline { 2 - 6 } Fertile egg, \% & $76.15 \pm 4.60$ & $85.55 \pm 5.29$ & $84.53 \pm 1.73$ & $89.86 \pm 2.49$ & $81.65 \pm 4.01$ \\
Hatchability, \% (total egg set) & $53.63 \pm 3.67$ & $64.22 \pm 5.47$ & $63.85 \pm 5.52$ & $67.84 \pm 3.51$ & $59.81 \pm 2.59$ \\
Hatchability, \% (fertile egg set) & $70.59 \pm 3.97$ & $75.07 \pm 4.20$ & $75.50 \pm 6.03$ & $75.41 \pm 2.24$ & $73.54 \pm 4.21$ \\
\hline
\end{tabular}

* No significant difference was found between the groups.

$\mathrm{n}=150$ eggs set the brooder for each group. 


\section{Discussion and Conclusion}

It has previously been demonstrated that MOS supplementation either has no effect $(14,15)$, or increases $(26,28)$ the live weight in poultry species. In this study, $0.5 \mathrm{~kg} /$ ton MOS supplementation to the diet of quail breeders significantly increased live weight compare to control and higher levels of MOS supplementation. Similar to İşcan and Güçlü (17) who found an increase in live weight of laying quail fed $0.5 \mathrm{~kg} / \mathrm{ton}$ of MOS supplemented diet. These authors also reported no effects of higher levels of MOS. On the other hand, probiotic supplementation had no effect on live weight in present study. This result supported the findings of the studies in layer's $(18,23,36)$.

Berry and Lui (6) found no significant effects of Bio-Mos supplementation to broiler breeder's diet on egg production. In contrast, in the present study, both probiotic and MOS supplementation increased the egg production, but significant increase was achieved by 0.5 $\mathrm{kg} /$ ton probiotic and $1 \mathrm{~kg} /$ ton MOS supplementations. The highest egg production was determined in $1 \mathrm{~kg} / \mathrm{ton}$ MOS supplemented group as in the studies reporting the improvements of egg production in laying hens by probiotics $(18,23,37)$ and by prebiotics $(7,8,17,33)$. The increased egg production by both probiotic and prebiotic may be due to the elongated small and large intestinal lengths as well as the their suppressing effects on undesirable bacteria and stimulating effects on the growth and/or activity of beneficial bacteria in the intestines which increase absorptive capacity $(7,12)$.

Lack of the effects of probiotic supplementation on feed consumption $(18,19,25)$, egg weight $(18,19,23,25)$ and feed efficiency $(19,23,25)$ in laying hens have been confirmed by the present study. These findings were also consistent with the results of Ayasan et al. (3) who investigated the effect of probiotic (protexin) supplementation in laying quail. In a study of Chen et al. (7), inulin and an oligofructose-type commercial prebiotic had no effect on feed consumption while improved feed efficiency in laying hens. However, in the present study, prebiotic (MOS) supplementation influenced neither feed consumption nor feed efficiency. Furthermore, lack of the effect of prebiotic on egg weight was consistent with the results of the study of Chen et al. (7). İşcan and Güçlü (17) also found no effect of MOS on egg weight in laying quail. On the other hand, Gracia et al. (13) reported a significant increase in average egg weight from 54 to 58 weeks with a tendency of increment up to 62 week of age in the MOS supplemented diet fed laying hens, but they did not find any positive effects thereafter. Lack of the effects of prebiotic and probiotic on the mentioned parameters in the present study may be due to the several factors such as differences in the chemical composition of the ingredients of the diet, differences in the levels (percentage) and main contents of the prebiotics used in the diet, adaptation, and the selectivity of the microflora and stress factors.

Some investigators $(5,18)$ found no effects of probiotics on egg specific gravity, while others $(20,23)$ reported improvements in egg shell thickness in laying hens. Consistent with the previous studies, egg shell thickness was significantly increased by the probiotic while the increase in specific gravity was not significant. Although, statistically not significant, increased specific gravity and shell thickness might suggest that probiotics may improve the egg shell quality due to the increased Ca absorption from the intestine $(20,23)$.

In the present study, egg shell thickness significantly but egg specific gravity was slightly increased by $0.5 \mathrm{~kg} /$ ton MOS supplementation. MOS had no significant effects on egg specific gravity in the previous studies conducted in laying hens $(4,33)$ and in broiler breeders (6). Although statistically not significant, determination of the highest egg specific gravity with 0.5 $\mathrm{kg} /$ ton MOS supplementation was consistent with the results of İşcan and Güçlü (17). An important correlation between increases in the absorption of minerals and fermentation of nondigestible oligosaccharides in the large intestine is existing (29). Thus, it can be suggested that the improvement in egg shell quality in this study might be resulted from the increased mineral absorption.

No effects of probiotic supplementation on Haugh unit was consistent with the results of the studies conducted on laying hens by Yalçın et al. (36), Pedrosa et al. (25) and Mahdavi et al. (19). Both probiotic and MOS supplementation had also no effects on albumen and egg yolk index whereas supplementation of MOS increased the yolk colour as in the study of Gracia et al. (13).

Nickolova et al. (21) reported no effects of probiotic supplementation on fertility and hatchability in muscov ducks. On the other hand, Shashidhara and Devegowda (32) found an increase in the percentage of fertile egg and hatchability in broiler breeders with $0.5 \mathrm{~kg} /$ ton MOS. In the present study, although statistically not significant, similar results were obtained with $0.5 \mathrm{~kg} /$ ton MOS supplementation. Both probiotic and $0.5 \mathrm{~kg} /$ ton $\mathrm{MOS}$ supplementation increased the fertile egg by $12 \%$ and $15 \%$ respectively. It can be suggested that the increase in hatchability may be due to the increased egg shell thickness (27).

Supplementation of probiotic and prebiotic to the diet of quail breeders improved egg production and egg shell thickness and positively affected hatchability in quail breeders. 


\section{Acknowledgments}

This project was supported by Erciyes University Scientific Research Project Unit (Project no: SBY-04-09)

\section{References}

1. Akbay R (1985): Bilimsel Tavukçuluk. Güven Matbaası, Ankara, Türkiye.

2. AOAC (1984): Official Methods of Analysis of the Association of Official Analytical Chemists. $14^{\text {th }}$ ed., Inc., Arlington, Virginia.

3. Ayasan T, Özcan BD, Baylan M, Canogulları S (2006): The effect of dietary inclusion of probiotic protexin on egg yield parameters of Japanese quails (Coturnix coturnix japonica). Int J Poult Sci, 5, 776-779.

4. Balander RJ (2006): Effect of bio-mos in replacement pullets and layers. Poultry Science Association, 95 th Annual Meeting Program, July 16-19, University of Alberta Edmonton, Canada.

5. Balevi T, Ucan US, Coskun B, Kurtoğlu V, Cetingül IS (2001): Effects of dietary probiotic on performance and humoral immune response in layer hens. Poultry Sci, 42, 456-461.

6. Berry WD, Lui P (2000): Egg production, egg shell quality and bone parameters in broiler breeder hen receiving Bio-Mos and eggshell 49. Poultry Sci, 79, 124 (Abstr).

7. Chen YC, Nakthong C, Chen TC (2005): Improvement of laying hen performance by dietary prebiotic chicory oligofructose and inulin. Int J Poult Sci, 4, 103-108.

8. Chukwu HI, Stanley VG (1997): Dietary Saccharomyces cervisiae and mannan oligosaccharide reduced the deleterious effects of heat stress on white leghorn laying hens. Association of Research Directors, Eleventh Biennial Research Symposium, Abstracts of Poster. October 1-4.

9. Ergün A, Tuncer ŞD, Çolpan İ, Yalçın S, Yıldız G, Küçükersan MK, Küçükersan S, Şehu A (2004): Yemler Yem Hijyeni ve Teknolojisi. Pozitif Matbaac1lık, Ankara.

10. Garcia LH (2003): Symposium: Probiotics and prebiotics. Biotecnol Aplic, 20, 189-194.

11. Gibson GR (2004): From probiotics to prebiotics and a healthy digestive system. J Food Sci, 69, 141-143.

12. Gibson GR, Roberfroid MB (1995): Dietary modulation of the human colonic microbiota: Introducing the concept of prebiotics. J Nutr, 125, 1401-1412.

13. Gracia MI, Cachaldora P, Tucker L, Baucells F, Medel P (2004): Effect of mannan oligosaccharides supplementation to laying hen diets. ADS ASAS PSA Annual Meeting, 25-29 July 673, (Abstr).

14. Güçlï BK (2003): The effect of mannanoligosaccharides on fattening performance of quails. Indian Vet $\mathrm{J}, \mathbf{8 0}$, 1018-1021.

15. Güçlü BK, İşcan KM (2006): Probiotic and mannan oligosaccharide on growth and biochemical parameters in turkey. Indian Vet J, 83, 1324-1326.

16. Hempe JM, Lauxen RC, Savage JE (1988): Rapid determination of egg weight and specific gravity using a computerised data collection system. Poultry Sci, 67, 902907.
17. İşcan KM, Güçlü BK (2000): The effects of using different enzyme mixtures and mannanoligosaccharide in quail rations containing maize and soybean on the performance. International Animal Nutrition Congress" 2000, Proceedings, 4-6 September, Isparta/Turkey, pp 5965.

18. Kurtoğlu V, Kurtoğlu F, Şeker E, Çoşkun B, Balevi T, Polat ES (2004): Effect of probiotic supplementation on laying hen diets on yield performance and serum and egg yolk cholesterol. Food Addit Contam, 21, 817-823.

19. Mahdavi AH, Rahmani HR, Pourreza J (2005): Effects of probiotic supplements on egg quality and laying hen's performance. Int J Poult Sci, 4, 488-492.

20. Mohan B, Kadirvel R, Bhaskaran M, Natarajan A (1995): Effect of probiotic supplementation on serum/yolk cholesterol and on egg shell thickness in layers. Br Poult Sci, 36, 799-803.

21. Nickolova M, Penkov D (2004): Experimental influence of Laktina probiotic on egg laying characteristics, fertility and viability in muscovy duck (Cairina Moshcata). J Cent Eur Agric, 5, 353-358.

22. Özdamar K (2002): Paket Programlar ile Istatistiksel Veri Analizi. 4. Baskı. Kaan Kitabevi, Eskişehir.

23. Panda AK, Reedy MR, Rama Rao SV, Praharaj NK (2003): Production performance, serum/yolk cholesterol and immune competence of white leghorn layers as influenced by dietary supplementation with probiotic. Trop Anim Healt Prod, 35, 85-94.

24. Patterson JA, Burkholder KM (2003): Application of prebiotic and prebiotics in poultry production. Poultry Sci, 82, 627-631.

25. Pedrosa AA, Moraes VMB, Ariki J (2001): Performance and egg quality from 50 to 66 weeks-old-laying-hens supplemented probiotic. Cienc Rural, 31, 683-686.

26. Pelicano ERL, Souza PA, Souza HBA, Leonel FR, Zeola NMBL, Boiago MM (2004): Productive traits of broiler chickens fed diets containing different growth promoters. Brazilian J Poult Sci, 6, 177-182.

27. Roque L, Soares MC (1994): Effect of eggshell quality and broiler breeder age on hatchability. Poultry Sci, 73, 1838-45.

28. Santin E, Maiorka A, Macari M (2001): Performance and intestinal mucosa development of broiler chickens fed diets containing saccharomyces cerevisiae cell wall. J Appl Poultry Res, 10, 236-244.

29. Scholz-Ahrens KE, Ade P, Marten B, Weber P, Timm W, Asil Y, Glüer CC, Schrezenmeir J (2007): Prebiotics, probiotics, and synbiotics affect mineral absorption, bone mineral content, and bone structure. J Nutr, 137, 838-846.

30. Seker I (2003): Bıldırcınlarda kuluçkalık yumurtaların döllülük oranına ve kuluçka sonuçlarına bazı faktörlerin etkisi. YYÜ Vet Fak Derg, 14, 42-46.

31. Shane SM (2001): Mannan oligosaccharides in poultry nutrition: mechanism and benefits. In: Science and Tecnology in the Feed Industry. Lyons T.P and Jacques K.A.(eds) Proceeding of Alltech's 17 th Annual Symposium. Nottingham University Press, Nottingham, NG110AX, United Kingdom, pp 65-77. 
32. Shashidhara RG, Devegowda G (2003): Effect of dietary mannan oligosaccharide on broiler breeder production traits and immunity. Poultry Sci, 82, 1319-1325.

33. Stanley VG, Brown C, Sefton T (2000): Single and combined effects of dietary protease and mannanoligosaccharide on the performance of laying hens. Poultry Sci, 79, 62.(Abstr).

34. Thompson BK, Hamilton RMG (1982): Comparison of the precision and accuracy of the specific gravity of eggs. Poultry Sci, 61, 1599-1605.

35. Wells RG (1968): A Study of Hen's Egg. In Carter, T.C. British Egg Marketing Board Symposium, Edinburgh, pp.207-249.

36. Yalçın S, Kahraman Z, Gürdoğan T, Dedeoğlu HE, Kocaoğlu B (2000): Ayçiçeği küspesi kapsayan yumurta tavuğu rasyonlarında enzim ve probiotik kullanımı" 1Verim üzerine etkisi. Tav Araş Derg, 2, 25-32.
37. Yörük MA, Hayirlı A, Macit M (2004): The effects of supplementation of humate and probiotic on egg production and quality parameters during the late laying period in hens. Poultry Sci, 83, 84-88.

Geliş tarihi: 10.10.2008 / Kabul tarihi: 22.01.2010

\section{Yazıșma adresi:}

Berrin Kocaoğlu Güçlü

Erciyes Üniversitesi Veteriner Fakültesi

Barlş Manço Cad., Kocasinan, Kayseri, Turkey,

E-mail:berrinkg@hotmail.com 